\title{
IAMJ
}

INTERNATIONAL

AYURVEDIC

MEDICAL JOURNAL

ISSN: 2320-5091

Impact Factor: 6.719

\section{STUDY OF KANDUGHNA EFFECT OF KARANJADI LEPA IN TWAK VIKAR (SKIN DISEASES)- A REVIEW}

\author{
Vibha Patwardhan ${ }^{1}$, Aruna Ojha ${ }^{2}$ \\ ${ }^{1}$ Final year PG Student, ${ }^{2} \mathrm{HOD}$, \\ Department of Kaya Chikitsa, Shri NPA Government Ayurvedic College Raipur, Chhattisgarh, India
}

Corresponding Author: Vibhapatwardhan12@gmail.com

https://doi.org/10.46607/iamj1309032021

(Published online: March 2021)

Open Access

(C) International Ayurvedic Medical Journal, India 2021

Article Received:10/02/2021 - Peer Reviewed:17/02/2021 - Accepted for Publication:18/02/2021

(A) Check for updates

\section{ABSTRACT}

Skin is the largest organ in the body. Among five sense organs (Gyanendriya) Twacha (skin) is one of them according to Ayurveda skin is site of Bhrajak Pitta. In normal state it is responsible for Prabha, Kanti. When it gets vitiated give rise to many Twak Vikar(Kushtha). In Samhita Grantha total 18 Kushtha (7 Mahakushtha, 11 Kudrakushtha) are described. As far as management of Kushtha is concern so many treatment modalities have described in Ayurveda, Lepa Kalpana is one of them. Lepa is topical application over the skin, it is described under Bhahiparimarjan Chikitsa. Karanjadi Lepa is mainly Kaphavatahar properties, its contents are Karanja, Kustha, Chakramard and Gomutra.

Keywords: Skin, Twacha, kandu, itching, Lepa, Ayurveda.

\section{INTRODUCTION}

The skin is the largest organ in the body and covers the body entire external surface. It includes sweat gland, hair and nails. ${ }^{[1]}$ According to ancient Ayurvedliterature Twacha (skin) is place of Bhraja Pitta which resides beneath the skin which is responsible for Kanti. ${ }^{[2]}$ When it gets vitiated it leads to many TwakVikar(skin disorder). In Samhita Grantha Acharya have mentioned total 18Twak Vikar in the name of 
Kushtha. Among them 7 classified as Mahakushtha while 11categorized under kshudra Kushtha. [3][4][5]. Kushtha is mainly Tridoshaja Vyadhi, having dominance of Kapha Dosha. General clinical manifestations of Kushtha are Kandu (itching), Ruja (pain), Vaivarnya (discolouration) etc. Acharya Chraka mentioned Kandu in Udumbara Kustha (Dosha-Pitta), Dadru, Charmadal, Pama, (Dosha-Pittakapa), Vicharchika (Dosha-Kapha). ${ }^{[6]}$ Acharya Sushruta mentioned Kandu in Pundrika, Daadru, Raksha, Sidhma (Dosha-Kapha) Charmadal, Vicharchik, Vipadika, Ktibha, Pama, Kachchu, KaphajaKilasha, Twachagat and Raktagat Kushtha. ${ }^{[7]}$ Acharya Vagbhat mentioned Kandu in Mandal, Pundrika, Vicharchika, Kitibha, Alshaka, Vipadika, Dadru, Pama, Charmadal. ${ }^{[8]}$ Kandu (itching ) is mainly due to Kapha Dosha. ${ }^{[9]}$ Its management explained as Sanshodhana and Sansaman Chikitsa respectively Antahparimarjan and Bahya Parimarjan Chikitsa and Nidhan Parivarjana. The word Twacha is derived from "Twak Sanwarnne" Dhatu Which means the covering of the body. According to ShabdaKalpadrum "Which covers the body is Twacha". [10] Acharya Sushrut has told about the 7 layer of skin which are Avabhashini, Lohita, Sweta, Tamra, Vedini, Rohani, Mashdhara whose thickness are 1/18, 1/16, 1/12, 1/8, 1/5 , 1, 2 Brihi (rice) respectively. ${ }^{[11]}$ Among these Tamra and Vedini are considered as site for Kushtha. In modern science skin covers the external surface of the body and it includes glands, hair and nails. Thickness of skin varies from place to place in the body. Two main layers of skin are Epidermis, and Dermis. Epidermis is outermost layer and5 sub layers consistsstratum corneum, stratum lucidium, stratum granulosum, stratum spinosum, stratum germinativum and surprisingly these layers does not have vasculature. Dermis is innermost layer having 2 sub layers superficial named papillary while deeper namedreticular. Functions of skin are protection, sensory, storage, absorptive, synthetic, regulation of body temperature and water and Electrolytes balance and so on Absorption of water soluble substances through the skin is almost negligible but certain lipid soluble materials possess the ability to penetrate the skin. ${ }^{[12]}$ Vata, Pitta,
Kapha Doshas, are responsible for Kandu in different way. When Vatai s vitiated it cause Rukshata (dryness), and Kharata (roughness) in body, which leads to Kandu. Vataj type of Kandu is associated with neurology and degenerative changes. Pitta is explained in two type Drava Pitta and Adrava Pitta, Drava Pitta works like vitiated Kapha, increased amount of Dravata leads to decrease in Ushna Guna of Pitta and increase in fluidity leads to Kandu. When Ushna Guna of Pitta is increases, Drava Guna decreases which result in shrinkage of cell due to imbalance in Pitta Guna, which lead to decrease metabolism and cell damage. Death of cell and debris increase (excessive dryness), which leads to Kandu. Vitiation of Kapha is main cause of Kandu (itch). Increase in fluidity leads to Gauravta in body, causes Agnimadya at cellular level, formation of Ama (toxins), enters in circulation. Sticky nature of Kapha causes blockage in small Strotas (channels). Less oxygen supply and accumulation of fluid at cellular level causes edema. Atmosphere of frequent infection is created showing damp condition in that part of body which attracts bacteria, fungi and facilitates their growth. In Ayurveda Kandu is mainly considered as Kushtha having dominance of Kapha Dosha although it is TridoshajVyadi. ${ }^{[13]}$ Some physiological condition in which itching is present i.e., in old age, in winter season which is particularly due to dryness of skin(due to decrease in Snehansh of body. Some foods which trigger the itching is Vartaak (brinjal), Sura $n$ (elephant foot), Raj(dust), some pollen grains etc. Also there are some group of medications which can provoke itching under some adverse condition these are Antibiotics i.e. erythromycin, tetracyclines, rifamcin, vancomycin Cardiovascular i.e. dilitiazem, verampil, captropil Psychotropic medicine i.e. Amitriptyline, sertaline, phenytoin Opioids i.e. Morphine, Codeine, Tramadol.

Lepa: In Lepa Kalpana wet and dried drugs are grinned to form paste and powder respectively and mixed with liquid medium such as Gomutra, Dugdha, Ghrita, Jalaso on.$^{[14]}$ Acharya Sushruta has classified Lepa into three types Pralepa, Pradeha, Alepa. ${ }^{[15]}$ Acharya Sharanghara mentioned three types 
of Lepa Doshaghna, Vishagna, Varnya. ${ }^{[16]}$ Acharya Vagbhat described ten types of Lepa viz. Snaihika, Nirwapan, Prasadana, Stambhana, Vilayana, Pachana, Pidan, Shodhan, Shoshana, Savarnikaran. ${ }^{[17]}$ Thickness of Lepa Acharya Sushruta "Buffalos skin" which is considered approximately 4-5 mm. ${ }^{[18]}$ Doshaghana $\quad$ Lepa $1 / 4 \quad$ Angula (0.48cm.)Vishaghana ${ }_{1 / 3}$ Angula $(0.65 \mathrm{~cm}$.) Varnya Lepa is 1/2 Angula (0.97cm). ${ }^{[19]}$ Paralepa is SheetaGuna, Tanu, two types of this Lepa Vishoshi, Avishoshi. Pradeha is either Sheeta are Ushna Guna, thick or thin, Avishoshi. Alepa lies in between the properties of Pralepa and Pradeha. ${ }^{[20]}$

\section{General rules of Lepa application ${ }^{[21]}$}

Lepa is for instant use and single use only. Lepa are applied against the direction of hair follicle as it facilitates its fast and better absorption. Once Lepa get dry it should be removed. Lepa is contraindicated at night. Karanjadilepa $^{[22]}$

Karanjadi Lepa comprises of Karanj (Pongamiapinnata), Kustha (Saussurealappa), Chakramarda (Cassia torra), seeds of these drugs are grind to form the fine powder and later mixed with Gomutra (cow urine). Contents of Karanjadi Lepa are described in following table:

Table 1

\begin{tabular}{|c|c|c|c|c|c|c|c|c|c|}
\hline $\begin{array}{l}\text { S. } \\
\text { N. }\end{array}$ & $\begin{array}{l}\text { Drug } \\
\text { Name }\end{array}$ & $\begin{array}{l}\text { Botanical } \\
\text { Name }\end{array}$ & Family & Rasa & Guna & Virya & Vipaka & Dosha-Karma & Activ Compound \\
\hline 1. & Karanj & $\begin{array}{l}\text { Pongamiapin- } \\
\text { nataLinn. }^{[23]}\end{array}$ & $\begin{array}{l}\text { Legumi- } \\
\text { nosae }\end{array}$ & $\begin{array}{l}\text { Tikta, } \\
\text { Katu }\end{array}$ & $\begin{array}{l}\text { Laghu, } \\
\text { Tikshna }\end{array}$ & Ushna & Katu & $\begin{array}{l}\text { Kaphavat } \\
\text { Samak, } \\
\text { Kusthaghna, } \\
\text { Kandughna } \\
{[24,25]}\end{array}$ & $\begin{array}{l}\text { Anti inflammatory } \\
\text { (Flavones) } \\
\text { Antimicrobial (Cal- } \\
\text { cone97, Trterpenes, } \\
\text { Immuno-modullator }^{[26,27]}\end{array}$ \\
\hline 3. & $\begin{array}{l}\text { Chakrama } \\
\text { rda }\end{array}$ & Cassia torra ${ }^{[31]}$ & $\begin{array}{l}\text { Legumi- } \\
\text { nosae }\end{array}$ & Katu & $\begin{array}{l}\text { Laghu, } \\
\text { Ruksha }\end{array}$ & Ushna & Katu & $\begin{array}{l}\text { Kaphavat } \\
\text { Samak, } \\
\text { dadrughna } \\
\text { [32] }\end{array}$ & $\begin{array}{l}\text { Anti inflammatory } \\
\text { Anti oxidant Antibacteri- } \\
\text { al }{ }^{[33]}\end{array}$ \\
\hline
\end{tabular}

Gomutra- Kinchita Madhur Rasa, Guna- Tikshna,Ruksha, Karma- Doshaghna, Krimikusthanut, Antioxidentanti-microbial, wound healing property and promotes the synthesis of interleukin $1 \& 2 \operatorname{IgA}$, IgG, IgM, T lymphocytes thus promotes immunity. ${ }^{[34]}$ Mode of action of Lepa

Lepa are applied against the direction of hair follicle to facilitate the absorption of drug by Romakupa(hair root), Sweda Vahini Granthi (sweat gland). ${ }^{[35]}$ Bhrajaka Pitta metabolizes the active principles of drugs applied over the skin this action is governed by Saman Vayu and Vyan Vayu. The theory of Srotomay Purush indicates that whole body is porous when the drugis applied in the form of Lepa the drug particles penetrates deeper into the skin through these pores. In this whole process Upashoshana property of Vyan and Saman Vayu plays profound role. Lepa metabolizes and acts according to properties of herbs may be due to Rasa, Guna, Virya, Vipaka or Prabhav. ${ }^{[36]}$ In modern medicine route of drug penetration is transepidermaleither intra cellular or intercellular. Inter cellular penetration/absorption through stratum cornium layer corneocytes, terminal differentiated keratinocytes allows the transport of hydrophilic or polar solutes. Inter cellular spaces allow diffusion of lipophilic or nonpolar solutes through the continuous lipid matrix. The trans appendagial route involves the passage of molecules through sweat gland and the hair follicles. ${ }^{[37]}$ This Lepa is mainly Tikta, Katu Ras Pradhan. Tikta Ras possess Lekhan, Kusthprasaman, Kledawsoshan, 
Lashikaawsoshan, PuyaAwsoshan, Kanduprasaman, Kusthaprasaman properties and it is Vata and Pitta Samak. ${ }^{[38,39]}$ Katu Ras having Sodhan, KledAwsoshan, Kandu Vinasan, and it is VataSamak properties. ${ }^{[40,41]}$ TikshanGuna having Sodhan properties. Laghu Guna is Lekhna, Kaphaghna properties and Ruksha Guna has Soshan properties. ${ }^{[42,43]}$ Gomutra facilitates the penetration due to its Tikshna and Sodhan properties. ${ }^{[4]}$

\section{DISCUSSION}

Kandu (itching) is a major symptom in skin diseases. Its mainly due to Kaphadosha, Vata and Pitta Dosha are also responsible for Kandu. When the drug is applied in the form of Lepa the drug particles penetrate deeper into the skin through Pores. Lepa metabolizes and acts according to properties of herbs may be due to Rasa, Guna, Virya, Vipaka or Prabhav. KaranjadiLepa having mainly Tikta, Katu Rasa Pradhana. Tikta Ras possess Lekhan, Kusthprasaman, Kledawsoshan, Lashikaawsoshan, PuyaAwsoshan, Kanduprasaman, Kusthaprasamanproperties and it is Vata and Pitta Samak. Katu Ras havines Sodhan, Kled Awsoshan, KanduVinasan, and it is VataSamak properties. Tikshan Guna having Sodhan properties. Laghu Guna is Lekhna, Kaphaghna properties and Ruksha Guna has Soshan properties. Karanajadi Lepa having TridoshaSamak properties. According to modern science Itching (pruritus) is an unpleasant sensation that leads to scratching or rubbing. Itching is a earliest manifestation of most of the skin diseases. Itching perceives in the skin by unspecialized free unmylinated nerve ending located in and around the dermoepidermal junction as well as intra epidermal. Signals are transmitted through unmylinated slow conducting $\mathrm{C}$ fibers through spinothalamic tract. ${ }^{[45]}$ Clinical classification of itching is 1 . Skin derived pruritus 2. Neuropathic pruritus 3. Neurogenic pruritus. Possible mode of action of itching 1.Mediator related pruritus (a)Aminnes (histamine,serotonin) (b) Proteases (c) Cytokines-Interleukins (d) Peptides (badykinin, substance $\mathrm{P}$, calcitonin gene related peptide, neutrophin, opioid peptides) (e) Phospholipid Medtabolites (cannabinoids, eicosanoids, platelet activating factor
2.Mechnisms of Signaling Pathway (histamine dependent, histamine independent) 1.Mediator related pruritus Histamine - Histamine is reserve in the mast cell and basophilic leukocyte, when these cells are activated histamine is induced to release. Its receptors $\mathrm{G}$ protein-coupled receptors, $\mathrm{H} 1$ and $\mathrm{H} 4$ receptors play important roles in the appearance of pruritus. Histamine could increase the calcium influx in the axon terminals of the spinal cord neurons and then promote a series of intracellular signal activation and ultimately lead to itching generation. Serotonin Serotonin derived from mast cell, which may induce pruritus through the central and peripheral mediation. Periphery by encouraging mast cell to release histamine. Proteases - Proteases combining to GPCR called proteases activated receptors (PAR2 and PAR4). Cytokines-Interleukins - Interleukins are group of cytokines containing secreted proteins and signal molecules. ${ }^{[46]}$ Medicine route of drug penetration is transepidermal either intra cellular or inter cellular. Inter cellular penetration/absorption through stratum cornium layer having keratinocytes allows the transport of hydrophilic or polar solutes. Inter cellular spaces allow diffusion oflipophilic or non-polar solutes through the continuous lipid matrix. The trans appendage route involves the passage of molecules through sweat gland and the hair follicles.

\section{CONCLUSION}

Kushtha is Trishoshaj Vyadhi. Kandu (itching) Kapha Dosha Pradhan Vyadhi. Karanjadi Lepa is mainly Kaphavathar properties. It is Katu, Tikta Ras Vipak Katu and Ushna Virya. Tikta and Katu Ras is Rakta Sodhan properties. Tikta and Katu Ras is Kapha and Pitta Samak, Ushna Guna is Vata and Kapha SamakKaranjadi Lepa act on Tridoshasamak mainly KaphaSamak properties help to treat the Kandu Lakshana of Kustha Vyadhi. Karanja, Kustha, Chakramard are anti-inflammatory properties and these drugs are anti-microbial, anti-bacterial, and immunomodulator properties are helping to treat itching. 


\section{REFERENCES}

1. Hani Yousef, Mandy Alhajj, Sandeep Sharma, Anatomy,Skin (Integument),Epidermis, StarPearls, Treasure Island(FL),2020 Jan PMID;29262154.

2. Vagbhata, Ashtanga Hrudaya, Dr. Bhrahmanad Tripathi, Sutrasthana Chapter 12/14, Chaukhambha Sanskrit Pratishthan Delhi, Reprint 2012, Page no

3. Agnivesa, Charaka Samhita, Dr, Bhrahmanad Tripathi, Nidansthana Chapter 5/4, ChaukhambaSurbharati Prakasthan Varanasi, Print 2013, Page no 624.

4. Susruta, Susruta Samhita, Kaviraj Ambikadutta Shastri, Nidansthana Chapter5/5, Chaukhamba Sanskrit Sansthan Varanasi, Reprint 2015, Page no 320.

5. Vagbhata, Ashtanga Hrudaya, Dr. Brahmanad Tripathi, Nidansthana Chapter 14/7-9, Chaukhamba Sanskrit Pratisthan Delhi, Reprint 2015, Page no 528.

6. Agnivesa, Charaka Samhita, Dr, Bhrahmanad Tripathi, Chikitsasthana Chapter 7/15,23,24,25,26, Chaukhamba Surbharati Prakasthan Varanasi, Print 2013, Page no 303-305.

7. Susruta, Susruta Samhita, Kaviraj Ambikadutta Shastri, Nidansthana Chapter5/8-22, Chaukhamba Sanskrit Sansthan Varanasi, Reprint 2015, Page no 321-324.

8. Vagbhata, Ashtanga Hrudaya, Dr. Brahmanad Tripathi, Nidansthana Chapter 14/17,20,22,23,24,26,28, Chaukhamba Sanskrit Pratisthan Delhi, Reprint 2015, Page no 529-531.

9. Charaka Samhita, Hindi commentary, Vd. Harish Chandra Singh Kushwaha, Part2, Chikitsasthana Chapter7/36, Chaukhambha Orientalia Varanasi, reprint 2018, Page no 200.

10. Shabdakalpadrum, by Raja Radha Kauta Deva, Part 2, chowkhambasankrit Series Office Varanashi, Page no.667.

11. Susruta, Susruta Samhita, Kaviraj Ambikadutta Shastri, Shrirasthana Chapter4/4, Chaukhamba Sanskrit Sansthan Varanasi, Reprint 2015, Page no 37.

12. Gerard J. Tortora, Bryan Derrickson, Principles of Anatomy and Physiology, 12 Edition, Volume 1, Page no. $148,160,161$.

13. Dr. Shubhagi Masugade, Dr. Jyoti Meghdambar and Dr. S.R. Saley, Differential Dignosis of Kandu in Various TwakVikara (Skin Disorders), European Journal of Pharmaceutical and Medical Research, 2017.

14. Prof. K. R. Srikantha Murthy, Sarngadhara Samhita, Utterkhanda11/1, Chaukhmbha Orientalia,2012, Page no 235 .
15. Susruta, Susruta Samhita, Kaviraj Ambikadutta Shastri, Sutrasthana Chapter18/6, Chaukhamba Sanskrit Sansthan Varanasi, Reprint 2015, Page no 97

16. Sharangdhar Samhita, Dr. Smt. Shailaja Srivastava, Utara khand, Chapter11/1, Chaukhambha Orientalia A House of Oriental and Antiquarian Books Varanasi, Reprint Edition 2017, Page no 424.

17. Angadi Ravindra, Texbook of Bhaishajya Kalpana Vijana, $2^{\text {nd }}$ Edition, Chukhambha Surbharti Prakashan, 2016, Page no 349-359.

18. International Journal of Green Pharmacy, OctDec2015, Shilpa Patil, Anand Kumar Chaudhary, Topical Dosages Froms (Lepa Kalpana) of Ayurveda: An Unexplored Treasure.

19. Review Article, Chaudhari Tejaswini, Kubde Sneha, Dive Mukund, Jamnekar Pallavi, Role of Lepakalpana For Improving Beauty of Skin W.S.R. to Mukhalepa, International Journal of Ayurveda and Pharma Research, May2017|Vol 5| Issue 5.

20. Susruta, Susruta Samhita, KavirajAmbikadutta Shastri, Sutrasthana Chapter18/6, Chaukhamba Sanskrit Sansthan Varanasi, Reprint 2015, Page no 97.

21. Review Article, Chaudhari Tejaswini, Kubde Sneha, Dive Mukund, Jamnekar Pallavi, Role of Lepakalpana For Improving Beauty of Skin W.S.R. to Mukhalepa, International Journal of Ayurveda and Pharma Research, May2017|Vol 5| Issue 5.

22. Agnivesa, Charaka Samhita, Dr, Bhrahmanad Tripathi, Sutrasthana Chapter 3/13, Chaukhamba Surbharati Prakasthan Varanasi, Print 2013, Page no 63.

23. API (The Ayurvedic Pharmacopoeia of India), Part 1 Volume 1Goverment of India Ministry of Health and Family Welfare Department of India Systems of medicine And Homoeopathy, Reprint 2001, Page no 63.

24. Database on Medicinal Plants Used in Ayurveda, Volume 2, Central Council for Research in Ayurveda and Siddha Jawaharlal Nehru Bhartiya Chikitsa Avam Homoeopathy Anusandhan Bhavan 61-65 Institutional Area, opp. D Block, Janakpuri, New Delhi, Page no 292.

25. Dravyaguna Vigyaniy, Dr. J.L.N. Sastry, Volume 2, Chaukhambhaorientalia Vranasi, Reprint2016, Page no 167.

26. S. K. Bhandlirge, A. S. Tripathi, R. K. Bhandirge, T. P. Chinchmalatpure, H. G. Desai, A.V. Chandewar, Evaluation of Wound Healing Activity of Ethanolic Extract Of Pongamia Pinnata Bark, DOI http://dx.doi.org/10.1055/s-0034-1384537. 
27. L. M. R. Al Muqarrabun, N. Ahmat, S. A. S. Ruzaina, N. H. Ismail, I. Sahidin, Medicinal uses, phytochemistry and pharmacology of Pongamiapinnata (L.) Pierre:A review, Journal of Ethnopharmacology, 2013, DOI.org/10.1016/j.jep.2013.08.041.

28. Database on Medicinal Plants Used in Ayurveda, Volume 7, Central Council for Research in Ayurveda and Siddha Jawaharlal Nehru Bhartiya ChikitsaAvam Homoeopathy Anusandhan Bhavan 61-65 Institutional Area, opp. D Block, Janakpuri, New Delhi, Page no 244.

29. Dravyaguna Vigyaniy, Dr. J. L. N. Sastry, Volume 2, Chaukhambha Orientalia Vranasi, Reprint 2016, Page no 307.

30. Jae Youl Cho, Kyong Up Baik, Jee H. Jung, Myung Hwan Park, In vitro anti-inflammatory effects of cynaropicrin, a sesquiterpene lactone, from Saussurealappa, European Journal of Pharmacology, 2000, DOI: 10.1016/S0014-2999(00)00337-x.

31. Database on Medicinal Plants Used in Ayurveda, Volume 2, Central Council for Research in Aurveda and Siddha Jawaharlal Nehru Bhartiya ChikitsaAvam Homoeopathy Anusandhan Bhavan 61-65 Institutional Area, opp. D Block, Janakpuri, New Delhi, Page no 144.

32. Dravyaguna Vigyaniy, Dr. J. L. N. Sastry, Volume 2, Chaukhambha Orientalia, Vranasi, Reprint2016, Page no 274.

33. Smita Jain and U K Patil, Phytochemical and Pharmacological profile of Cassia torra Linn. -An Overview, Indian Journal of Natural Products and Resources, 2010,

34. Sreepada Kanale, Antioxidant and Anti-inflammatory Activities of Cow Urine From Malnad Gidda-An Indigenous Breed, International Journal of Pharmaceutical Sciences and Research, DOI: 10.13040/IJPSR./0975-8232.10(2).612-18.

35. Susruta, Susruta Samhita, Kaviraj Ambikadutta Shastri, Sutrasthana Chapter18/4, Chaukhamba Sanskrit Sansthan Varanasi, Reprint 2015, Page no 96.

36. Chaudhari Tejaswini, Kubde Sneha, Dive Mukund, Jamnekar Pallavi, Role of Lepakalpana for Improving Beauty of Skin W.S.R. to Mukhalepa, International Journal of Ayurveda and Pharma Research, IJAPR May2017 | vol.5 | Issue 5.

37. Ahlam Zaid Alkilani, Maeliosa T.C. Mc Crudden and Ryan f. Donnelly, Transdermal Drug Delivery Innovative Pharmaceutical Developments Based on Disruption of the Barrier Properties ofthe Stratum Corneum,
DOI no; 10.3390/pharmaceutics7040438 PMID;26506371.

38. Susruta, Susruta Samhita, Kaviraj Ambikadutta Shastri, Sutrasthana Chapter 42/16, Chaukhamba Sanskrit Sansthan Varanasi, Reprint 2015, Page no 204.

39. Charaka Samhita, Shri Satya Narayan Sastri, Part1, Sutrastana, Chapter 26/42(5), Chaukhambhabharati Academy Varanasi, Reprint 2013, Page no 507.

40. Susruta, Susruta Samhita, Kaviraj Ambikadutta Shastri, Sutrasthana Chapter42/15, Chaukhamba Sanskrit Sansthan Varanasi, Reprint 2015, Page no 203.

41. Charaka Samhita, Shri Satya Narayan Sastri, Part1, Sutrastana, Chapter 26/42(4), Chaukhambhabharati Academy Varanasi, Reprint 2013, Page no 506.

42. Vagbhata, Ashtanga Hrudaya, Dr. Brahmanad Tripathi, Nidansthana Chapter 1/18, Chaukhamba Sanskrit Pratisthan Delhi, Reprint 2015, Page no 15.

43. Susruta, Susruta Samhita, Kaviraj Ambikadutta Shastri, Nidansthana Chapter46/523-526, Chaukhamba Sanskrit Sansthan Varanasi, Reprint 2015, Page no 289.

44. Shobhit Kumar, Pharmacodynamics Study of Patoladi Kashaya and Karanjadi Lepa in Vicharchika W.S.R. Eczema, Ayurpharma Int J Ayur Alli Sci., Vol. 5, 2016.

45. Davidson's Principles and Practice of Medicine, Brian R. Walker, Nicki R. Colledge, Stuart H. Ralston, Ian D. Penman, Chapter28, Churchill Livingstone Elsever, Edinburgh London New York Oxford Philadelphia St Louis Sydney Toronto 2014, Edition 22, Page no 1258.

46. Jing Song, Dehai Xian, Lingyu Yang, Xia Xiong, Rui Lai, and Jianqiao Zhong, Pruritus: Progress Towaed Pathogenesis and Treatment, Biomed Research International, Volume 2018, doi.org/10.1155/2018/9625936.

\section{Source of Support: Nil \\ Conflict of Interest: None Declared}

How to cite this URL: Vibha Patwardhan \& Aruna Ojha: Study Of Kandughna Effect Of Karanjadi Lepa Intwak Vikar (Skin Diseases) - A Review. International Ayurvedic Medical Journal \{online\} 2021 \{cited March, 2021\} Available from: http://www.iamj.in/posts/images/upload/595 600.pdf 